\title{
Larry E. Smith's scholarly publications: A bibliography
}

\author{
Kingsley Bolton ${ }^{1}$ | Daniel R. Davis ${ }^{2}$ \\ ${ }^{1}$ School of Humanities, Nanyang Technological University, Singapore \\ ${ }^{2}$ Department of Language, Culture, and Communication, University of Michigan-Dearborn, \\ USA \\ Abstract
}

This article presents a bibliography of Larry Smith's publications over a period of thirty-four years from 1971 until 2015 (shortly after Larry's passing). The bibliography attests to Larry's creativity and originality, which helped shape the scope and range of so much of the world Englishes (WE) activities, including its openness and sensitivity to cross-cultural communication, and deeply-felt respect for multicultural and multilingual diversity.

\section{1 | INTRODUCTION}

As all the articles in this special issue attest, Larry Smith made a special contribution to world Englishes research and publications throughout a scholarly career that began in the early 1970s, and ended with his premature passing in 2014. The bibliography below classifies his research output into two broad categories, that is, 'world Englishes' (including studies of English as an International Language, intercultural communication, and intelligibility), and 'leadership and training', which, for Larry, became a major area of interest in the 1990s and 2000s (see the article by Elizabeth Christopher, this issue). In total, the bibliography below lists 18 books (co-authored and edited), 43 journal articles, and 29 book chapters. Despite these impressive totals, however, it bears repeating that in the case of Larry Smith, his contribution far exceeded the sum of the respective parts, and also involved his innovative efforts in co-founding the World Englishes journal, as well as the International Association for World Englishes (IAWE), together with Professors Braj B. and Yamuna Kachru.

\section{1 | Publications on world Englishes (including English as an International Language, intercultural communication, and intelligibility)}

Books

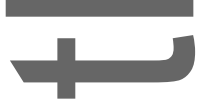

Kachru, Y., \& Smith, L. E. (2008). Cultures, contexts, and world Englishes. London: Routledge. Kriengkraipetch, S., \& Smith, L. E. (1992). Value conflicts in Thai society: Agonies of change seen in short stories. Bangkok: Social Research Institute, Chulalongkorn University Press \& Honolulu East-West Center.

This is the author manuscript accepted for publication and has undergone full peer review but has not been through the copyediting, typesetting, pagination and proofreading process, which may lead to differences between this version and the Version of Record. Please cite this article as doi: 10.1111/weng. 12342 .

This article is protected by copyright. All rights reserved. 
Lim, S. G.-L., Smith, L. E., \& Dissanayake, W. (1999). Transational Asia Pacific: Gender, culture and the public sphere. Urbana, IL: University of Illinois Press.

Masavisut, N., Simson, G., \& Smith, L. E. (Eds.). (1995). Gender and culture in literature and film East and West: Issues of perception and interpretation: Selected conference papers. Honolulu: College of Languages, Linguistics, and Literature, University of Hawaii: EastWest Center.

Smith, L. E. (Ed.). (1981). English for cross-cultural communication. London: Palgrave Macmillan.

Smith, L. E. (Ed.). (1983). Readings in English as an international language. Oxford: Pergamon Press.

Smith, L. E. (Ed.). (1987). Discourse across cultures: Strategies in world Englishes. London: Prentice Hall.

Smith, L. E., \& Rieder, J. (Eds.). (1996a). Changing representations of minorities East and West: Selected essays. Honolulu, HI: University of Hawaii Press.

Smith, L. E., \& Rieder, J. (Eds.). (1996b). Multiculturalism and representation: Selected essays. Honolulu: College of Languages, Linguistics, and Literature, University of Hawaii.

Smith, L. E., \& Forman, M. L. (Eds.). (1997). World Englishes 2000. Honolulu: University of Hawaii Press.

Via, R. A., \& Smith, L. E. (1983). Talk and listen: English as an international language via dramatechniques. Oxford: Pergamon Press.

Weiner, E. S., \& Smith, L. E. (1983). English as an international language: A writing approach. Oxford: Pergamon Press.

\section{Journal articles}

Bolton, K., Smith, L. E., \& Sridhar, S. N. (2015). Professor Yamuna Kachru's scholarly work: A bibliography. World Englishes, 34(1), 164-168.

Campbell, D., Ekniyom, P., Haque, A., \& Smith, L. E. (1982). English in international settings: Problems and their causes. English World-Wide, 3(1), 66-76.

Kachru, B.B., \& Smith, L. E. (1986). Introduction. World Englishes, 5(2-3), 115-118.

Kachru, B. B., \& Smith, L. E. (1995). Introduction. World Englishes, 14(1), 1-2.

Kachru, B. B., \& Smith, L. E. (2011). Editorial notes. World Englishes, 30(1), 2.

Kachru, B. B., \& Smith, L. E. (2015). Editorial notes. World Englishes, 34(1), 2.

Kachru, Y., \& Smith, L. E. (2009). The Karmic cycle of world Englishes: Some futuristic constructs. World Englishes, 28(1), 1-14.

Kriengkraipetch, S., \& Smith, L. E. (1991). Value conflicts in Thai society. Journal of Communication Arts, Special Issue, 12, 36-43.

Smith, L. E. (1971a). Readers' reactions: Practical guide to individualization, by Harry Reinert. Modern Langyage Journal, 55(6), 389-396.

Smith, L. E. (1971b). Don't teach: Let them learn. TESOL Quarterly, 5(2), 149-151.

Smith, L. E. (1972). An individualized seminar in American culture and English as a second language at the Culture Learning Institute, East-West Center. Paper presented at The sixth annual TESOL convention, Washington, DC. 1 March. Published as Working Paper 11 at the East-West Culture Learning Institute.

Smith, L. E. (1974). What is individualism in TESL? TESL Reporter, 8(1), 1-2 \& 12. 
Smith, L. E. (1975a). The art of change in ESOL or how to create an elephant. TESL Reporter, 9(1), 4-5.

Smith, L. E. (1975b). Teaching English in Asia: An overview. Culture Learning, 3, 133-136.

Smith, L.E.(1976a). English as an international auxiliary language. RELC Journal, 7(2), 38-42.

Smith, L. E. (1976b). English for international communication. TESL Reporter, 9(3), 3.

Smith, L. E. (1976c). ESOL-EIAL: A position paper on the teaching/learning of English as an international auxiliary language. TESL Reporter, 10(1), 2-4.

Smith, L. E. (1978). Some distinctive features of EIIL vs. ESOL in English language education. The Cultural Learning Institute Report (East-West Center), 5(3), 5-7 \& 10-11. Also in 1983, L. E. Smith (Ed.), Readings in English as an international language (pp. 13-20). Oxford: Pergamon Press.

Smith, L. E. (1980). Don't teach - let them learn. Bulletin de l'ACLA/Bulletin of the CAAL, April, 51-54

Smith, L. E. (1981). English as an international language: No room for linguistic chauvinism. Nagoya Gakuin Daigaku Gaikokugo Kyoiku Kiyo, 3. 27-32. Also in 1983, L. E. Smith (Ed.), Readings in English as an international language (pp. 7-11). Oxford: Pergamon Press.

Smith, L. E. (1983). The five senses of teaching/learning English as an international language. PASAA, 13(1), 77-81.

Smith, L. E. (1984a). A communicative approach to teaching English as an international language. Cross Currents: A Journal of Language Teaching and Cross-Cultural Communication, 11(1), 37-48.

Smith, L. E. (1984b). Teaching English as an international language. Studium Linguistik, 15, 52-59.

Smith, L. E. (1985). EIL versus ESL/EFL: What's the difference and what difference does the difference make? English Teaching Forum, 23(4), 2-6.

Smith, L.E. (1986). Cross-cultural understanding and English literatures from the other Circles. World Englishes, 5(2-3), 241-248.

Smith, L. E. (1988a). The role of English in Thailand: Transition and tradition. PASAA, 18(1), $1-5$.

Smith, L. E. (1988b). Who are the best English teachers in Thailand. PASAA, 18(1), 6-9.

Smith, L. E. (1989). What was that you called me? Forms of address in cross-cultural interactions. PASAA, 19(2), 130-135.

Smith, L. E. (1991). Standards in world Englishes. ERIC, document ED 347795, 1-10.

Smith, L. E. (1998). English is an Asian language. Asian Englishes, 1(1), 172-174.

Smith, L. E. (2003). Symposium on world Englishes today (part I): Introduction. World Englishes, 22(4), 403.

Smith, L. E. (2004). Exploring new dimensions in Asian Englishes. Asian English studies, 6, 523.

Smith, L. E. (2005). Introduction. World Englishes, 24(2), 159.

Smith, L. E. (2015a). English as an international language: No room for linguistic chauvinism. Journat of English as a Lingua Franca, 4(1), 165-171.

Smith, L. E. (2015b). Speech act, politeness, the Yamuna Kachru model. World Englishes, 34(1), 133-135.

Smith, L. E., \& Bisazza, J. A. (1982). The comprehensibility of three varieties of English for college students in seven countries. Language Learning, 32(2), 259-269. 
Smith, L. E., Crookes, G., Tang, F., Liu, D., \& Xue, Z. (2000). Increasing creativity and innovation in English language teaching in China. Teaching English in China, 23(3), 2-4.

Smith, L. E., \& Long, J. R. (2000). Literacy, writing systems, and development in the Pacific. Studies in the Linguistics Sciences, 30(1), 169-182.

Smith, L. E., \& Mack, F. R. (1971). Practical guide to individualization, Harry Reinert. The Modern Language Journal, 55(6), 389-392.

Smith, L. E., \& Nelson, C. L. (1985). International intelligibility of English: Directions and resources. World Englishes, 4(3), 333-342.

Smith, L. E. \& Rafiqzad, K. (1979). English for cross-cultural communication: The question of intelligibility, TESOL Quarterly, 13(3), 371-380.

Smith, L. E., \& Sridhar, S. N. (1992). Introduction. World Englishes, 11(2-3), 85-89. S

mith, L. E., \& Via, R. A. (1982). Talk and listen: English as an international language via drama techniques. World Englishes, 1(3). 102-107.

\section{Book chapters}

Fujimori, D. L., Odo, B. M. T., \& Smith, L. E. (2015). Hit the ground running enhancing international students' cross-cultural adjustment. In E. Christopher (Ed.), International management and intercultural communication (pp. 62-74). London: Palgrave Macmillan.

Kachru, B. B., \& Smith, L. E. (1988). World Englishes: An integrative and crosscultural journal of WE-ness. In R. Maxwell \& Pergamon Press, 40 Year's service to science, technology and education (pp. 674-678). Oxford: Pergamon Press.

Smith, L. E. (1983a). English as an international auxiliary language. In L. E. Smith (Ed.), Readings in English as an international language (pp. 1-5). Oxford: Pergamon Press.

Smith, L. E. (1983b). English as an international language: No room for linguistic chauvinism. In L. E. Smith (Ed.), Readings in English as an international language (pp. 7-11). Oxford: Pergamon Press.

Smith, L. E. (1983c). Some distinctive features of EIIL vs. ESOL in English language education. In L. E.Smith (Ed.), Readings in English as an international language (pp. 13-20). Oxford: Pergamon Press.

Smith, L. E. (1987). Introduction: Discourse strategies and cross-cultural communication. In L. E. Smith (Ed.), Discourse across cultures: Strategies in world Englishes (pp. 1-8). New York: Prentice Hall.

Smith, L. E. (1988a). Language spread and issues of intelligibility. In J. E. Alatis (Ed.), Language spread and language policy: Issues, implications and case studies (Georgetown University Round Table on Languages and Linguistics 1987) (pp. 265-282). Washington, DC: Georgetown University Press.

Smith, L. E. (1988b). Teaching and learning English as an international language in China. In W. Hu (Ed.), Intercultural communication (pp. 167-183). Shanghai: Shanghai Translations Publishing House.

Smith, L. E. (1990a). Religious/cultural values versus development: Reflections in modern Thai literature. In J. Toyoma \& N. Ocker (Eds.), Literary relations East and West. Hawaii: University of Hawaii Press. 
Smith, L. E. (1990b). Teaching English as an international language in Japan: Criterial attributes of the best teachers. In Linguistic fiesta: Festschrift for Professor Hisao Kahehi's sixtieth birthday (pp. 199-209). Tokyo: Kurosio Press.

Smith, L. E. (1991). Standards in world Englishes. In M. L. Tickoo (Ed.), Languages \& standards: Issues, attitudes, case-studies (pp. 33-41). Singapore: SEAMEO Regional Language Centre.

Smith, L. E. (1992). Spread of English and issues of intelligibility. In B. B. Kachru (Ed.), The other tongue: English across cultures (pp. 75-90). Urbana, IL: University of Illinois Press.

Smith, L. E. (1995). Pragmatic transfer: A Japanese speaking English is a JAPANESE speaking English. In Committee for the Publication Project, Department of English Language Education, Faculty of Education, Hiroshima University (Ed.), Studies in English language education: A collection of essays (pp. 3-12). Hiroshima: Keisuisha Publishing Company.

Smith, L. E. (1996). Representations of the Isan, an important minority in Thailand. In L. E. Smith \& J. Rieder (Eds.), Changing representations of minorities East and West (pp. 188196). Honolulu, HI: University of Hawaii Press.

Smith, L. E. (1998). Is English THE language of international leadership? In J. H. O'Mealy \& L. E. Lyons (Eds.), Language, linguistics, and leadership: Essays in honor of Carol M. K. Eastman (pp. 109-114). Honolulu, HI: University of Honolulu Press.

Smith, L. E. (2001). International communication in world Englishes. In C. K. Tong, A. Pakir, K. C. Ban \& R. B.H. Goh (Eds.), Ariels: Departures \& returns: Essays for Edwin Thumboo (pp. 91-103). Oxford: Oxford University Press.

Smith, L. E. (2003). English across cultures: The problem of intelligibility. In G. French \& J. d'Angelo (Eds.), First conference on world Englishes in the classroom: Proceedings (pp. 52-59). Nagoya: Chukyo University College of World Englishes.

Smith, L. E. (2004). From English as an International Auxiliary Language to world Englishes. In Y. Otsubo \& G. Parker (Eds.), Development of a teacher training program (pp. 72-80). Tokyo: Soueisha/Sanseido.

Smith, L. E. (2009). Dimensions of understanding in cross-cultural communication. In K. Murata \& J. Jenkins (Eds.), Global Englishes in Asian contexts: Current and future debates (pp. 17-25). New York: Palgrave Macmillan.

Smith, L. E. (2013). The future of English as the world's primary language of wider communication. In Y. Takeshita (Ed.), Look! We have come through! The 15th anniversary of the Japanese Association for Asian Englishes (pp. 8-20). Tokyo: The Japanese Association for Asian Englishes.

Smith, L. E (2014). Teaching English as an International Language (EIL) in Hawaii: The case of the Global Cultural Exchange Program. In T. Shiozawa, T. Enokizono, Y. Kurahashi, T. Komiya \& M. Shimouchi (Eds.), Gendaishakai to eigo [World Englishes in changing society] (pp. 133-139). Tokyo: Kinseido.

Smith, L. E., \& Christopher, E. (2001). Why can't they understand me when I speak English so clearly? In E. Thumboo (Ed.), The three Circles of English: Language specialists talk about the Engtish language (pp. 91-100). Singapore: UniPress. Also in 2006, K. Bolton \& B. B. Kachru (Eds.), World Englishes: Critical concepts in linguistics (Vol. 4, pp. 82-90). London: Routledge.

Smith, L. E., \& Nelson, C. L. (2006). World Englishes and issues of intelligibility. In B. B. Kachru, Y. Kachru \& C. L. Nelson (Eds.), The handbook of world Englishes (pp. 428-445). Oxford: Wiley-Blackwell. 
Smith, L. E., \& Tawake, S. (1992). Culture as reflected in creative literature. In R. Ahrens \& H. Antor (Eds.), Text-culture-reception: Cross-cultural aspects of English studies (pp. 351564). Heidelberg: Carl Winter, Universitatsverlag.

Smith, L. E., \& Tawake, S. (1993). Write like an author: Pacific and Asian literatures as a resource for teaching composition. In M. N. Brock \& L. Walters (Eds.), Teaching composition around the Pacific Rim: Politics and pedagogy (pp. 35-47). Philadelphia, PA: Multilingual Matters.

Smith, L. E. \& Tawake, S. (1995). Creative literature, culture and comprehension. In M. L. Tickoo (Ed.), Language and culture in multilingual societies: Viewpoints and visions (pp. 260-277). Singapore: SEAMEO Regional Language Centre.

Sukwiwat, M., \& Smith, L. E. (1981). TESOL and training non-native speakers: Are M. A. teacher education programs getting the job done? In J. C. Fisher, M. A. Clarke, \& J. Schachter (Eds.), On TESOL '80: Building bridges: Research and practice in teaching English as a Second Language (pp. 3-14). Washington, DC: WATESOL.

\section{Conference papers}

Smith, L. E. (2004). English is an Asian language. Conference proceedings of PAC5 at FEELTA 2004, Sharing Challenges, Sharing Solutions: Teaching Languages in Diverse Contexts, Far Eastern University, Vladivostok, Russia, 2005. 36-38.

\section{Encyclopedia entries}

Smith, L.E. (1992a). English as an International Language. In T. McArthur (Ed.), The Oxford companion to the English language. Oxford: Oxford University Press.

Smith, L. E. (1992b). International communication. In T. McArthur (Ed.), The Oxford companion to the English language. Oxford: Oxford University Press.

Smith, L. E. (2002). English in Asia. In D. Levinson \& K. Christensen et al. (Eds.), Encyclopedia of modern Asia. New York: Charles Scribner's Sons.

Smith, L. E. (2003). English language, role in international communications. In D. H. Johnston (Ed.), Encyclopedia of international media and communication (Vol. 1, pp. 523-528). San Diego, CA: Academic Press.

\section{Interview}

Sines, A. (2006). Interview with Larry Smith. East-West Center Oral History Project Collection. Honolulu, Hawaii: East-West Center.

\section{2 | Leadership and training}

\section{Leadership books}

Christopher, E. M., \& Smith, L. E. (1991). Negotiation training through gaming: Strategies, tactics and manoeuvres. London: Kogan Page.

Smith, L. E. (2014). Self-leadership: Direction from within. E-book. 
Smith, L. E., \& Christopher, E. M. (1987). Leadership training through gaming: Power, people and problem-solving. New York: Nichols Pub. Co.

Smith, L. E., \& Christopher, E. M. (1994a). Leadership training: A sourcebook of activities.

Smith, L.E., \& Christopher, E. M. (1994b). Managing recruitment training and development: A sourcebook of activities. London: Kogan Page.

Smith, L. E. \& Christopher, E. M. (2007). Training activities: Leadership training. New Delhi: Viva Books.

\section{Book chapters}

Sawyer, M., \& Smith, L. E. (1994). Approaching cultural crossover in language learning. In R. W. Brislin \& T. Yoshida (Eds.), Improving intercultural interactions: Modules for crossculturaltraining programs (pp. 295-312). Thousand Oaks, CA: Sage.

Smith, L. E., \& Christopher, E. M. (1990). Shaping the context of simulation/games. In D. Crookall \& R. Oxford (Eds.), Simulation, gaming, and language learning (pp. 47-54). New York: Newbury House, Harper \& Row.

\section{ACKNOWLEDGEMENTS}

We would like to express our gratitude to Ms Charlotte Choo, Ms Evangeline Lin and Mr Christian Teo of the School of Humanities of Nanyang Technological University, Singapore, for their valuable assistance in compiling and formatting this bibliography.

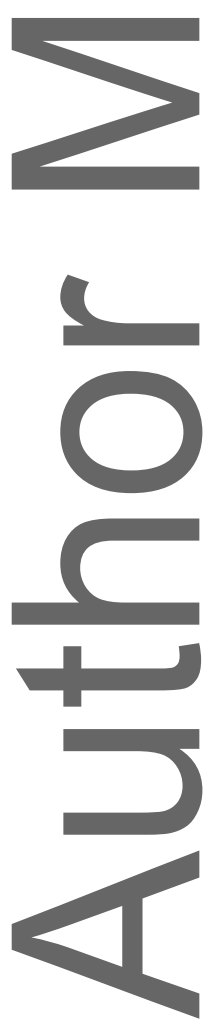

